\title{
RADIOMORPHOMETRIC EVALUATION OF MANDIBULAR CORTICAL INDEX AMONG YOUNG AND MIDDLE-AGED LITHUANIAN INDIVIDUALS
}

\author{
Remigijus Laurinčikas, Eglẻ Jagelavičienė, Aistė Ratkevičienė, Dominyka Grinkevičienė \\ Department of Dental and Oral Diseases, Lithuanian University of Health Sciences
}

Keywords: mandible, mandibular cortical index, panoramic radiography, osteoporosis.
Summary
Background and objective. The aim of this study was morphological analysis of the cortical layer in the mandibular base distally from the mental foramen for determination of the mandibular cortical index in the Lithuanian young and middle-aged individu- als according to gender, age, general health status, used medicine.
Materials and methods. The study included 216 ran- domly selected subjects aged 19 to 50 years. A qu- estionnaire was used to collect data on subjects' age, gender, sociodemographic status, diseases, and used medicines, harmful habits. Skeletal bone status was examined according One - Minute test, panoramic radiography was performed, and panoramic radio- graphic images were analyzed to determine the man- dibular cortical index. According to the classification by Klemetti, subjects were divided into 3 index morp- hological groups: $\mathrm{C} 1, \mathrm{C} 2$, and $\mathrm{C} 3$. Analysis was car- ried out by mentioned factors.
Results. There was a significant relationship between mandibular cortical index and subject's age $(F=4.54$; $d f=2 ; p=0.01)$, gender $(\alpha 2=16.22 ; d f=2 ; p<0.01)$, thy- roid diseases $(p=0.05)$, hormonal preparation use $(p<0.01)$, cigarette smoking $(p<0.01)$.
Conclusions: The study data confirmed the hypothe- sis that morphological changes in the cortical layer at the mandibular base were found among young and middle aged individuals with normal skeletal bone status and were significantly associated with subject's age, gender, and other factors such as cigarette smo- king, diseases having an influence on bone metabo- lism, used medicines.

\section{Introduction}

Literature data show that people attend dental practices more frequently than family medicine clinics, and panoramic radiography performed for diagnostic purposes is one of the most commonly performed radiological investigations in dental practice $[1,2]$. Panoramic radiography carried out for the development of primary dental treatment plan allows to evaluate patient's periodontal status, cariogenic and periapical lesions, quality of endodontic treatment; to preliminary investigate jaws before implant placement; and to evaluate cortical and trabecular bone tissue. However, changes in the cortical layer of the jaws can occur not only due to dental reasons such as tooth loss, altered occlusal and chewing function, rotations of the mandible, altered muscle-to-bone alignments, and changes in locations of muscle attachments in the mandible, but also due to physiological differences in bone remodeling, individual's diet, inheritance factors, metabolic and other diseases, used medicines, or can differently manifest in subjects of a different gender [3, 4].

The need for panoramic radiography is constantly increasing, and currently this method can be applied in order to diagnose diseases of skeletal bone tissue, i.e., osteopenia and osteoporosis (OP), or to detect calcification of the external carotid artery and osteogenesis imperfecta [5-7]. Changes in the cortical layer of the mandibular base on panoramic radiographic image have been studied across the world for a long time and knowledge as well as experience is employed in general medical clinical practice by comparing the changes in skeletal bone tissue of different bones [4, 8-13]. Recently, special attention has been paid to research on the mandibular cortex of healthy and osteopenia subjects of different age and gender according to panoramic radiomorphometric indices in different races and populations $[4,11,14,15,16,17$, 18 ], and most commonly such research is linked to skeletal bone mineral density. Diagnostic evaluation of changes in both skeletal and mandibular bone tissue remains relevant 
in dental and medical practice in Lithuania as well $[3,19]$.

Mandibular cortical index (MCI) is a qualitative radiomorphometric index that evaluates changes in the cortical layer of the mandibular base distally from the mental foramen and is linked to changes in skeletal bone mineral density $[11,20]$. Research shows that bone mass, density, and dynamic processes in women and men differ [16]. Most of the studies, related to osteoporosis prevention and treatment, on MCI changes have investigated the elderly population and women more frequently than men, because changes in women's bone tissue are more rapid and especially become active during the postmenopausal period [3,21]. In this study we formulated and attempted to confirm the hypothesis that not only metabolic diseases (such as OP) affect the bone but the resorption and porosity of the mandibular cortical layer and formation of endosteal cortical residues can appear because of different reasons in young and middle-aged individuals who do not have any symptoms characteristic of metabolic bone diseases and have normal skeletal bone mineral density, and do not belong to the risk group.

The aim of the study was to evaluate the cortical layer of the mandibular base distally from the mental foramen according to Klemetti [20] seen on panoramic radiograms of 19-50-year-old subjects, considering subjects' age, gender, diseases, used medicines.

\section{Materials and methods}

The study was carried out in the Clinic of Dental and Oral Diseases and the Clinic of Dental and Maxillofacial Orthopedics, Lithuanian University of Health Sciences (LUHS), Kaunas, Lithuania. Kaunas Regional Biomedical Research Ethics Commitee approved this study (No. BE-2-3). A total of 19- to 50-year-old 216 subjects who attended the Clinic of Dental and Maxillofacial Orthopedics, Lithuanian University of Health Sciences, and who underwent dental panoramic radiography due to diagnostic purposes were invited to take part in the study. The subjects were selected based on the set criteria to be included in the study: age from 19 to 50 years, good general health and oral health status, no dental surgical procedures at the mental foramen of the mandible within 6 months before the study, presence of teeth in the alveolar ridge in the region of the mental foramen and their antagonists in the maxilla (mechanical bone load is ensured), and no implants in this region. In order to obtain more extensive study results, smokers were not excluded from the study. The main exclusion criteria were as follow: a lack of motivation to participate in the study, surgical dental treatment, and dental implantation in the mandible, and insufficient quality of panoramic radiographic images, One - Minute test results by the International Osteoporosis Foundation [22].
A questionnaire was prepared according International Osteoporosis Foundation (IOF) One - Minute test to determine skeletal bone status and was employed to collect data on social characteristics, gender, age, place of residence, education, oral health; causes, severity, and duration of gum bleeding; tooth loss by chronic periodontitis; dental surgery (implantation, tooth extraction, flap surgery, etc.); jaw and skeletal fractures due to non-severe trauma. The questions were used for gathering the data on the daily level of physical activity; diseases having an influence on bone metabolism (diabetes mellitus, hyperthyroidism, hypothyroidism, hyperparathyroidism, rheumatoid arthritis, osteoporosis); used calcium supplements, hormonal preparations, bisphosphonates, corticosteroids, vitamin D; bone mineral density testing; age at which women experienced menopause; and harmful habits (cigarette smoking).

\subsection{Panoramic radiography}

Morphological changes in cortical bone layer of the mandibular base were analyzed on panoramic radiograms, which were taken for diagnostic and treatment purposes at the Clinic of Dental and Maxillofacial Orthopedics, LUHS. Panoramic radiography was performed by an X-ray technician and the dentist who carried out this study. Panoramic X-ray machine CS 9000/CS 9000 3D (2013, USA) and Dental Imaging Software 6.14.7 were used (Carestream Health, Inc., 2014) in the study. Depending on the subject's build, exposure time was 4 to $16 \mathrm{~s}$; anode current, 8 to $10 \mathrm{~mA}$; anode voltage, 68 to $74 \mathrm{kV}$, and irradiation dose, $130 \mu \mathrm{Gy} / \mathrm{h}$. Panoramic radiograms were taken by complying with device operating instructions and positioning methodology according to the requirements by Dutra et al. [15]. Panoramic radiograms were coded based on the questionnaire code of the subject and were analyzed with image analysis and editing program Digimizer v.4.6.1 (2016).

\subsection{Analysis of mandibular cortical index}

Based on the classification by Klemetti [20], the appearance of the cortical bone layer distal from the mental foramen on both sides of the mandible was analyzed. According to the morphological changes, the subjects were divided into 3 groups: $\mathrm{C} 1$, the endosteal margin of the mandibular cortex is sharp and even; $\mathrm{C} 2$, the endosteal margin of the cortex

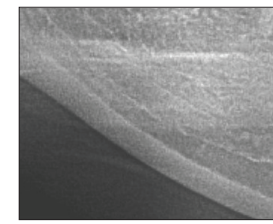

Group C1

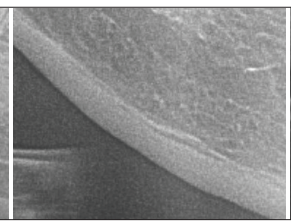

Group C2

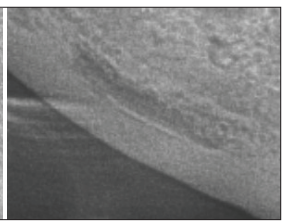

Group C3
Figure 1. Morphological groups according Klemetti (C1; C2; C3). 
shows semilunar defects (lacunar resorption) or seems to form 1 to 3 layers of endosteal cortical residues; and C3, the cortical layer forms heavy endosteal cortical residues and is clearly porous (Figure 1.) [20].

In order to ensure study precision and to evaluate agreement ( $\kappa$ coefficient), MCI was assessed by 3 researchers (main researcher and two independent researchers).

\subsection{Statistical analysis}

The software SPSS 22.0 was used for analyzing data. Quantitative variables are expressed as mean with standard deviation and median with $25 \%-75 \%$ percentiles. For statistical hypotheses testing, the significance level was set at 0.05 . The Kolmogorov-Smirnov test was applied to check the normality of distribution of quantitative variables. Quantitative variables between two groups were compared with the parametric Student $t$ and nonparametric Mann-Whitney test, while among three groups, parametric and nonparame-

Table 1. Distribution of the study population by gender and MCI morphological groups.

Values are number (percentage). $p$ value was determined by the nonparametric Pearson chi-square test; $\mathrm{MCI}$, mandibular cortical index; C1, C2, C3, morphological MCI groups.

\begin{tabular}{|lcc|}
\hline MCI group & \multicolumn{2}{c|}{$\begin{array}{c}\text { Gender } \\
\end{array}$} \\
\hline C1 & $28(18.7)^{*}$ & $3(4.5)^{*}$ \\
\hline C2 & $88(58.7)$ & $32(48.5)$ \\
\hline C3 & $34(22.7)^{* *}$ & $31(47.0)^{* *}$ \\
\hline \multicolumn{3}{|c|}{$\chi^{2}=16.219 ; d f=2 ; p<0.001 ;{ }^{*} p=0.007 ;{ }^{* *} p<0.001$} \\
\hline
\end{tabular}

Table 2. Respondents' age by MCI morphological groups. $p$ value was determined by the nonparametric Kruskal-Wallis and Mann-Whitney tests, MCI, mandibular cortical index; C1, C2, and C3, morphological MCI groups.

\begin{tabular}{|llll|}
\hline MCI group & $\mathrm{n}(\%)$ & \multicolumn{2}{c|}{ Age, years } \\
& & Mean (SD) & Median $(25 \%-75 \%)$ \\
\hline C1 & $31(14.4)$ & $31.4(7.1)^{*}$ & $31.0(25.0-37.0)$ \\
\hline C2 & $120(55.6)$ & $33.5(8.2)^{* *}$ & $32.5(26.0-41.0)$ \\
\hline C3 & $65(30.0)$ & $36.4(9.0)^{*},{ }^{*}$ & $39.0(29.0-43.5)$ \\
\hline \multicolumn{4}{|c|}{$\chi^{2}=8.831, d f=2, p=0.014 ;{ }^{*} p=0.007,{ }^{*} p=0.023$} \\
\hline
\end{tabular}

Table 3. Respondents' age by MCI morphological groups and gender.

$p$ value was determined by the nonparametric Mann-Whitney test; MCI, mandibular cortical index; $\mathrm{Cl}, \mathrm{C2}$, and $\mathrm{C3}$, morphological MCI groups.

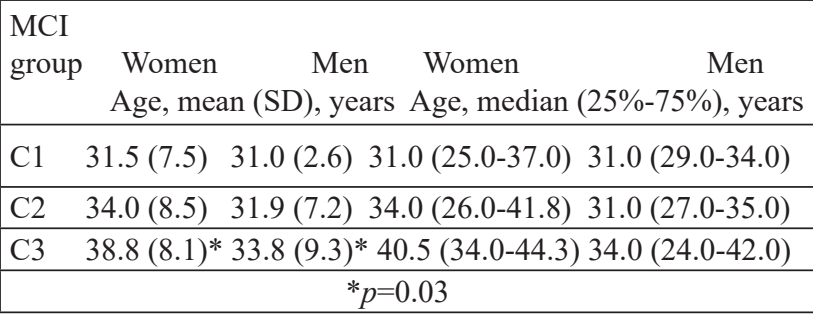

tric dispersion analysis (ANOVA and Kruskal-Wallis test).

To determine a relationship between qualitative variables, the chi-squared $\left(\chi^{2}\right)$ criterion was employed. Relationships between variables were evaluated with Spearman correlation analysis. Receiver operating characteristic (ROC) curve analysis was used to determine a threshold value for respondents' age; the area under the ROC curve (AUC) was calculated as well. To develop prognostic models, binary logistic regression analysis was applied. A sample size was calculated during a pilot study $(\mathrm{n}=110)$. Power of the study was set at $\beta=0.8$ and significance level, at $\alpha=0.05$.

\section{Results}

The study enrolled 216 respondents aged from 19 to 50 years; of them, there were $150(69.4 \%)$ women and 66 $(30.6 \%)$ men. The mean age of the total study population was 34.1 (8.4) years; the mean age of women and men was $34.6(8.6)$ and 32.7 (8.1) years, respectively. A total of 193 $(89.4 \%)$ respondents lived in the urban area and $155(71.8 \%)$ had higher education.

Panoramic radiographic images were analyzed and MCI assessment was done by the main and two independent investigators, and agreement between them was evaluated by Cohen kappa. $\kappa$ between the first and the second investigators was $0.93(p<0.01)$; between second and third, 0.92

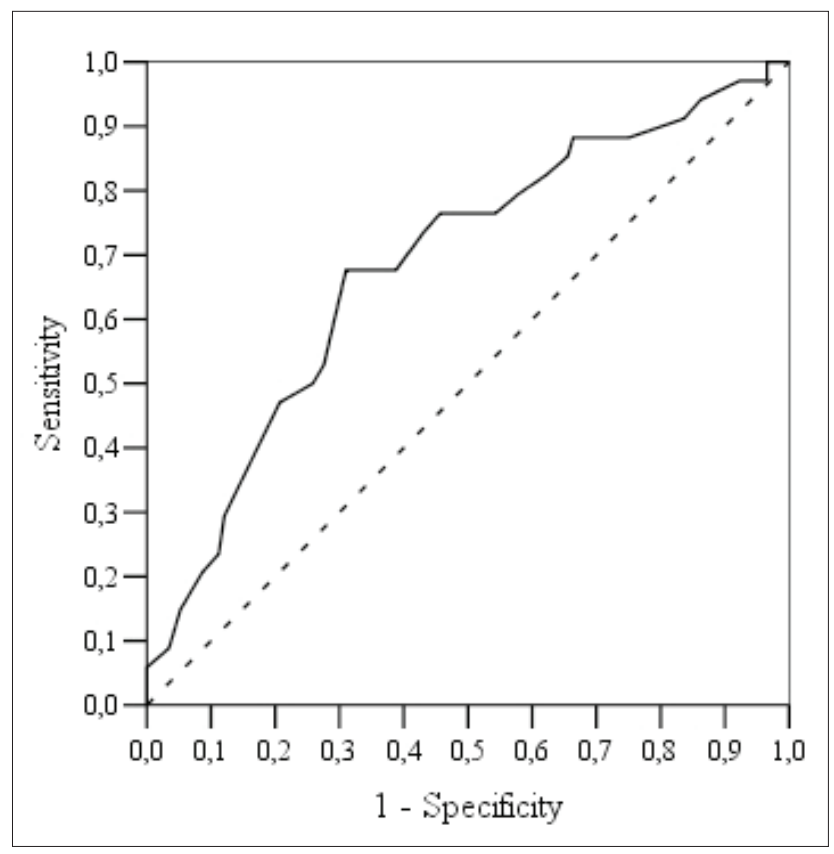

Figure 2. ROC curve for identifying a threshold value for age in women, considering MCI categories AUC, 68.4\%; sensitivity $67.6 \%$; specificity, $69.0 \%$. 
$(p<0.01)$; and between first and third; $0.90(p<0.01)$.

3.1. Analysis of mandibular cortical index

The results of our study showed that subjects' gender was significantly associated with the morphological MCI groups: the appearance of $\mathrm{C} 1$ category was more characteristic of the female gender, and the cortical layer of male subjects formed heavy endosteal cortical residues and was clearly porous more frequently, i.e., had the appearance of C3 category (Table 1). Binary logistic regression analysis revealed that men were 3 times as likely to be assigned to group C3 (OR=3.022; 95\% CI, 1.632-5.596).

Respondents' age by MCI groups is shown in Table 2.

The respondents in Groups $\mathrm{C} 1$ and $\mathrm{C} 2$ were significantly younger than their counterparts in Group C3.

Table 3 shows that in Group C3, men were significantly younger than women. ROC curve analysis showed a threshold value for age in the female study population to be 38.5 years (Figure 2.).

There were $36(31.0 \%)$ women in Groups $\mathrm{C} 1$ and $\mathrm{C} 2$ as well as $23(67.6 \%)$ women in Group C3, who were aged $>38.5$ years $(p<0.001)$. Binary logistic regression analysis revealed that women aged $>38.5$ years were nearly 5 times as likely to be assigned to Group C3 (OR $=4.646 ; 95 \% \mathrm{CI}$, $2.048-10.541)$. There were $5(14.3 \%)$ men aged $>38.5$ years in Groups C1 and C2 as well as $11(35.5 \%)$ in Group C3 $(p=0.045)$, and the odds of having the appearance of $\mathrm{C} 3$ category was 3 times greater for men aged $>38.5$ years ( $\mathrm{OR}=3.3$; 95\% CI, 0.995-10.946).

None of the men had thyroid diseases, rheumatoid arthritis, diabetes mellitus. The prevalence of these diseases among women was as follows: $11(7.3 \%)$ had thyroid diseases; 3 $(2.0 \%)$ rheumatoid arthritis; 2 (1.3\%), diabetes mellitus. Five

Table 4. Multivariate binary logistic regression analysis model showing predictors of the appearance of C3 category

\begin{tabular}{|llr|}
\hline Variable & \multicolumn{1}{c|}{ OR $(\mathbf{9 5} \% \mathbf{C I})$} & $\boldsymbol{p}$ \\
\hline Age of $>38.5$ years & $3.905(1.962-7.772)$ & $<0.001$ \\
\hline Tooth loss & $2.652(0.932-7.545)$ & 0.067 \\
\hline Cigarette smoking & $1.685(0.761-3.73)$ & 0.198 \\
\hline Male gender & $4.169(2.043-8.508)$ & $<0.001$ \\
\hline Constant $=-2.37 ; p<0.001$. Model Overall Percentage & $72.9 \%$ \\
\hline Final model 1 & 0.043 \\
\hline Tooth loss & 0.0375 \\
\hline Cigarette smoking & $2.147(1.049-4.393)$ & $<0.001$ \\
\hline Constant $=-1.088 ; p<0.001$. Model Overall Percentage $71.0 \%$ \\
\hline Final model 2 & 0.02 \\
\hline Male gender & $3.253(1.73-6.114)$ & \\
\hline Tooth loss & $3.224(1.198-8.674)$ & \\
\hline Constant $=-1.357 ; p<0.001$. Model Overall Percentage $70.1 \%$ \\
\hline
\end{tabular}

(4.3\%) women in Groups $\mathrm{C} 1$ and $\mathrm{C} 2$ as well as $6(17.6 \%)$ women in Group C3 had thyroid diseases $(p=0.009)$. Women with thyroid diseases were at a nearly 5 -fold greater risk of being assigned to Group $\mathrm{C} 3(\mathrm{OR}=4.757$; 95\% CI, $1.353-16.723)$. One (0.9\%) woman in Groups $\mathrm{C} 1$ and $\mathrm{C} 2$ as well as $2(5.9 \%)$ in Group C3 had rheumatoid arthritis $(p=0.129)$. Diabetes mellitus was present in $1(0.9 \%)$ woman in Groups C1 and C2 as well as in $1(2.9 \%)$ women in Group C3 $(p=0.403)$. Other diseases were recorded in 5 $(4.3 \%)$ women in Groups $\mathrm{C} 1$ and $\mathrm{C} 2$ as well as $1(2.9 \%)$ in Group C3 ( $p=0.72)$.

Hormonal preparations were used only by women: 4 (3.4\%) women in Groups $\mathrm{C} 1$ and $\mathrm{C} 2$ as well as $6(17.6 \%)$ in Group C3 used them $(p=0.004)$. Women who used hormonal preparations were almost 4 times as likely to be assigned to Group 3 (OR=3.737; 95\% CI, 1.018-13.723). Four (1.9\%) subjects reported using calcium supplements: $3(2.0 \%)$ in Groups $\mathrm{C} 1$ and $\mathrm{C} 2$ as well as $1(1.5 \%)$ in Group C3 $(p=1.0)$. Vitamin D was used by 19 (8.8\%) respondents: 12 (7.9\%) in Groups $\mathrm{C} 1$ and $\mathrm{C} 2$ as well as $7(10.8 \%)$ in Group C3 $(p=0.502)$.

Tooth loss by chronic periodontitis was recorded in 19 (8.9\%) respondents: $9(6.0 \%)$ in Groups $\mathrm{C} 1$ and $\mathrm{C} 2$ as well as $10(15.4 \%)$ in Group C3 $(p=0.027)$. Analysis by gender revealed that $14(9.4 \%)$ women and $5(7.7 \%)$ men lost their teeth $(p=0.687)$. Female and male respondents who lost their teeth were at almost 3-fold greater risk of developing the appearance of $\mathrm{C} 3$ category ( $\mathrm{OR}=2.828 ; 9 \% \mathrm{CI}, 1.091-7.335)$. Women who lost their teeth were 4 times as likely to be assigned to Group C3 (OR=4.0; 95\% CI, 1.293-12.374).

Table 5. Multivariate binary logistic regression analysis model showing predictors of the appearance of $\mathrm{C} 3$ category among women

\begin{tabular}{|llc|}
\hline Variable & OR $(95 \%$ CI) & $\boldsymbol{p}$ \\
\hline Age of $>38.5$ years & $4.351(1.815-10.427)$ & 0.001 \\
\hline Tooth loss & $3.781(1.105-12.938)$ & 0.034 \\
\hline Thyroid diseases & $3.553(0.826-15.274)$ & 0.088 \\
\hline Hormone use & $5.671(1.168-27.541)$ & 0.031 \\
\hline Constant $=-2.37 ; p<0.001$. Model Overall Percentage $79.9 \%$ \\
\hline Final model 1 & \\
\hline Age of $>38.5$ years & $4.257(1.817-9.975)$ & 0.001 \\
\hline Tooth loss & $3.639(1.096-12.086)$ & 0.035 \\
\hline Thyroid diseases & $4.606(1.211-17.522)$ & 0.025 \\
\hline Constant $=-2.37 ; p<0.001$. Model Overall Percentage $80.5 \%$ \\
\hline Final model 2 & $4.454(1.881-10.545)$ & 0.001 \\
\hline Age of $>38.5$ years & $3.777(1.091-13.073)$ & 0.036 \\
\hline Tooth loss & $<0.001$ \\
\hline Hormonal preparation use $6.862(1.585-29.7)$ & $78.5 \%$ \\
\hline Constant $=-2.37 ; p<0.001$. Model Overall Percentage
\end{tabular}


There were $40(18.5 \%)$ smokers in the overall study population: $20(13.3 \%)$ women and $20(30.3 \%)$ men $(p=0.003)$. Group C1 had 2 (6.5\%) smoking persons; Group C2, 20 (16.7\%), and Group C3, 18 (27.7\%). The percentage of smokers in Group C3 was significantly greater than in Groups 1 and $2(18(27.7 \%)$ vs. $22(14.6 \%), p=0.023)$. Being a cigarette smoker was associated with a 2-fold greater risk of developing the appearance of $\mathrm{C} 3$ category $(\mathrm{OR}=2.246,95 \%$ CI, 1.108-4.553).

\subsection{Prognostic analysis}

Table 4 presents the binary logistic regression analysis model. Gender, age, cigarette smoking, and tooth loss were univariate binary logistic regression analysis predictors significantly associated with the appearance of $\mathrm{MCI}$ C3 category.

Spearman correlation analysis showed that gender significantly correlated with cigarette smoking $(r=0.201, p=0.003)$ and age groups $(r=0.146, p=0.032)$. After screening for feature multicollinearity, final multivariate prognostic models $(1,2)$ were developed (Table 4).

Comparative analysis revealed that among women, age, hormone use, thyroid diseases, and tooth loss were significant predictors for developing the appearance of $\mathrm{C} 3$ category. There was a significant correlation between the presence of thyroid diseases and hormone use (Spearman $r=0.232$, $p=0.004)$. After screening for feature multicollinearity, final prognostic models $(1,2)$ were developed for the female study population (Table 5).

\section{Discussion}

Studies have shown that MCI, mostly linked to age- and osteoporosis-related changes in the mandibular cortical layer, is being evaluated more commonly in postmenopausal women (around the age of 50 years), and with advancing age, $\mathrm{MCI}$ category has a tendency to change [23-25]. Numerous panoramic radiomorphometric indices of the mandible and their relationships with skeletal bone mineral density as well as subjects' age and gender have been evaluated in different populations [12]. The questions if changes in the mandibular cortical layer may manifest, but may not be seen, in young and middle-aged subjects who are healthy and do not have major complaints due to metabolic bone diseases and reduced bone mineral density, and what causes may lead to these changes could be addressed. In this study, we attempted not only to analyze sociodemographic factors, harmful habits, and used medications, but also to subjectively evaluate periodontal status and to select only those subjects with an adequate mandibular function the area being investigated.

In this study the majority of the respondents had higher education and reported taking care of oral health. Nearly $60 \%$ of the respondents indicated the gingiva bleeding; some reported tooth loss by periodontal disease. This points out that there were subjects with different periodontal status in the studied group; however, the subjects enrolled in the study had teeth in the area for MCI determination and had adequate functional load in the mandible, which is important in studies on bone tissue. Physical load on bones of the skeletal system and occlusal forces on the jaws help maintain normal bone mass, and altered functional activity leads to changes in metabolic processes and structure of the bone [26, 27]. While investigating bone tissue, occasionally attention to individual's diet (consumption of dairy products, use of vitamin $\mathrm{D}$ and calcium) and physical activity is paid [3, 28-31]. The subjects included in this study did not have high levels of daily physical activity and did not consume dairy products as well as did not use calcium supplements and vitamin D frequently. All these features were not significantly related to subjects' age, gender, education, place of residence.

After analysis of MCI morphological data, we found that an even and regular cortical endosteal margin ( $\mathrm{C} 1$ category) was more typical for women, and the cortical layer with numerous endosteal residues and its porosity ( $\mathrm{C} 3$ category), for men. This contradicts the findings of the study by Bajoria et al., who reported more extensive changes in the mandibular cortical layer to be characteristic of the female gender [23]. It might be speculated that these differences could be caused by different distribution by gender across the studies.

Analysis of associations between MCI and respondents' age showed that with advancing subjects' age, MCI category increased significantly as well. These results are in agreement with the findings of the studies by Khojastehpour et al., Gulsahi et al., and Kavitha et al. [8, 11, 32]. The study by Kavitha et al. included the subjects with a wider age range, but the mean age of subjects with severely eroded cortices (C3 category) was also significantly greater than the mean age of subjects with mildly or moderately eroded (C2 category) and normal (C1 category) cortical layer.

Associations between MCI and age were investigated in the study by Govindraju and Chandra [33]. Our research as well as the above-mentioned study found that MCI categories were significantly related to subjects' age and gender. Govindraju and Chandra recruited 21- to 60-year-old subjects in their study and reported that the appearance of $\mathrm{C} 1$ category was more common among younger men and women, while the appearance of $\mathrm{C} 2$ and $\mathrm{C} 3$ categories was predominantly seen among older women: C2 category in 26-30-year-old female group and 31-35-year-old male group, C3 category in women around age of 41 age and in men around age of 51 years [33]. The results of our study regarding $\mathrm{C} 1$ category support the findings of this study and the results regarding $\mathrm{C} 2$ category correspond partly, but the age of men with $\mathrm{C} 3$ 
category was considerably lower.

Smoking was not an exclusion criterion in this study; therefore, it enrolled smokers as well. While analyzing the data, associations between MCI category and cigarette smoking were search. The present study showed that morphological changes in the cortical layer of the mandible were significantly associated with cigarette smoking: smokers more frequently appeared to be assigned to Group C3. However, we were unable to find previous studies on associations between these variables thus making comparison to the results reported by other authors impossible.

The present study found that thyroid diseases were more prevalent among older women. Moreover, associations between morphological changes in the cortical layer of the mandible and thyroid diseases were determined - women with thyroid diseases were at greater risk of developing the appearance characteristic of $\mathrm{C} 3$ category. It has been reported that altered thyroid functions can cause secondary osteoporosis [34]. The results of our study allows to make presumption that in such case MCI-related changes in the presence of thyroid diseases are possible, and it was confirmed by the results of logistic regression analysis. However, a larger scale study is needed for more extensive analysis of the issue being investigated.

In our study, there were subjects with rheumatoid arthritis, diabetes mellitus, and osteoporosis. However, the sample sizes of subjects with a particular disease were too small in order to determine significant relationships with the MCI or see tendencies. Limeira at al. analyzed MCI among individuals with type 1 Diabetes Mellitus. The authors declared mandibular cortical alterations in all age groups and in the both genders [35]. Moreover, we failed to prove an influence of vitamin D and calcium use on MCI category: subjects who used vitamin $\mathrm{D}$ and calcium belonged to all three morphological MCI groups and sample sizes were small. We did not find any studies analyzing analogous associations with the above-mentioned features.

In addition, this study enrolled subjects who used hormonal preparations and in our case, only women, having the appearance of $\mathrm{C} 2$ and $\mathrm{C} 3$ categories, used hormonal preparations. There was a significant association between thyroid diseases and hormonal preparation use, but we advocate that considering subjects' (female) age, also, the presumption of oral contraceptive use should not be ruled out. We think that these results can be questionable because there are studies reporting that oral contraceptives have a positive effect on bone mineral density [36, 37]. In our study, comparative (logistic regression) analysis revealed that hormonal preparation use was associated with the odds of being assigned to group $\mathrm{C} 3$.

\section{Conclusions}

The study data confirmed the hypothesis that morphological changes in the cortical layer at the mandibular base were found among young and middle aged individuals with normal skeletal bone status according One - Minute test and were significantly associated with subject's age, gender, and other factors such as cigarette smoking, diseases, used medicines.

\section{References}

1. Shintaku WH, Enciso R, Covington JS, Migliorati CA. Can dental students be taught to use dental radiographs for osteoporosis screening? Journal of Dental Education 2013; 77(5):598-603.

2. Watanabe PCA, Watanabe MG, de C, Tiossi R. How dentistry can help fight osteoporosis. Medicine, immunology, allergology and rheumatology "Osteoporosis". Yannis Dionyssiotis 2012; ISBN.

3. Eglè Jagelavičienè. A comparative analysis of mandibular and calcaneal bone mineral density in post-menopausal women [The doctoral dissertation]. Kaunas Medical University 2010.

4. Asha ML, Bajoria AA, Babshet M, Patil P, Naveen S. Bone mineral density measurement of the jaws-a review. J Investigative Dent Sci 2014;1(1).

5. Devlin CV, Horner K, Devlin H. Variability in measurement of radiomorphometric indices by general dental practitioners. Dentomaxillofacial Radiology 2001; 30(2):120-125.

https://doi.org/10.1038/sj.dmfr.4600594

6. Alapati S, Sudhakara R, Tatapudi R, Kotha R, Bodu NK, Chennoju S. Identifying risk groups for osteoporosis by digital panoramic radiography. 2015;6(1):253-257.

https://doi.org/10.4103/0976-237X.166833

7. Apolinario A, Sindeaux R, Figueiredo P, Guimar A, Acevedo A, Castro L, et al. Dental panoramic indices and fractal dimension measurements in osteogenesis imperfecta children under pamidro-nate treatment. Dentomaxillofacial Radiology 2016;45(4). https://doi.org/10.1259/dmfr.20150400

8. Kavitha MS, Park SY, Heo MS, Chien SI. Distributional variations in the quantitative cortical and trabecular bone radiographic measurements of mandible, between male and female populations of Korea, and its utilization. PLoS ONE 2016; 11(12).

https://doi.org/10.1371/journal.pone.0167992

9. Taguchi A. Triage screening for osteoporosis in dental clinics using panoramic radiographs. Oral Dis 2009 Aug 7. [Epub ahead of print].

10. Pavicin S, Dumancic I, Jukic J, Badel T, Badanjak A. Digital orthopantomograms in osteoporosis detection: mandibular density and mandibular radiographic indices as skeletal BMD predictors. Dentomaxillofacial Radiology 2014;43(7):el.

https://doi.org/10.1259/dmfr.20130366

11. Khojastehpour L, Afsa M, Dabbaghmanesh MH. Alterations 
of mandibular inferior cortex in postmenopausal osteoporosis. Iran Red Crescent Med J 2011;13(3):181-186.

12. Devlin H, Karayianni K, Mitsea A, Jacobs R, Lindh C, Paul $\mathrm{S}$, et al. Diagnosing osteoporosis by using dental panoramic radiographs: The OSTEODENT project. Oral Surg Oral Med Oral Pathol Oral Radiol Endod 2007; 104:821-8.

https://doi.org/10.1016/j.tripleo.2006.12.027

13. Taguchi A, Suei Y, Sanada M, Ohtsuka M, Nakamoto T, Sumida $\mathrm{H}$, et al. Validation of dental panoramic radiography measures for identifying postmenopausal women with spinal osteoporosis. AJR Am J Roentgenol 2004; 183:1755-60.

https://doi.org/10.2214/ajr.183.6.01831755

14. Mudda JA, Bajaj M, Patil VA. A Radiographic comparison of mandibular bone quality in pre- and post-menopausal women in Indian population. Journal of Indian Society of Periodontology 2010; 14(2):121-125.

https://doi.org/10.4103/0972-124X.70833

15. Dutra V, Yang J, Devlin H, Susin C. Radiomorphometric indices and their relation to gender, age, and dental status. Oral Surg Oral Med Oral Pathol Oral Radiol Endod 2005; 99(4):479-84. https://doi.org/10.1016/j.tripleo.2004.09.013

16. Bozdag G, Sener S. The evaluation of MCI, MI, PMI and GT on both genders with different age and dental status. Dentomaxillofac Radiol 2015; 44.

https://doi.org/10.1259/dmfr.20140435

17. Govindraju P, Chandra P. Radiomorphometric indices of the mandible an indicator of osteoporosis. Journal of Clinical and Diagnostic Research 2014; 8(3):195-198.

https://doi.org/10.7860/JCDR/2014/6844.4160

18. Yüzügüllü B, Gulsahi A, İmirzalioglu P. Radiomorphometric indices and their relation to alveolar bone loss in completely edentulous Turkish patients: a retrospective study. J Prosthet Dent 2009; 101:160-5.

https://doi.org/10.1016/S0022-3913(09)60021-4

19. Laurincikas R. Radiomorphometric evaluation of mandibular cortical index among different age and sex individuals. [Master's thesis] Kaunas LUHS 2017.

20. Klemetti E, Kolmakov S, Kroger H. Pantomography in assessment of the osteoporosis risk group. Scand J Dent Res 1994; 102(1):68-72.

https://doi.org/10.1111/j.1600-0722.1994.tb01156.x

21. Jagelavičienė E, Krasauskienė A, Žalinkevičius R, Vaitkevičiené I, Kubilius R. Relationship between the mandibular cortical index and calcaneal bone mineral density in postmenopausal women. Medicina, 2016; 52(2):125-131.

https://doi.org/10.1016/j.medici.2016.02.005

22. Hong-Mei Zhang, Hui-Ling Liu, Xuan Wang, Wei Chen, Dan Chen, Zhong-Zhi Zhang, HanMing Wang. Clinical value of self-assessment risk of osteoporosis in Chinese. Open Med 2016;11:190-195.

https://doi.org/10.1515/med-2016-0036
23. Asha ML, Kamath G, Babshet M, Patil P, Sukhija P. Evaluation of radiomorphometric indices in panoramic radiograph - a screening tool. The Open Dentistry Journal 2015; 9(2):303-310. https://doi.org/10.2174/1874210601509010303

24. Majumder MI, Harun M A. Alveolar bone changes in postmenopausal osteopenic and osteoporosis women: an original research. IJDMS 2010; 12(3):93- 96;

25. Knezović Zlatarić D, Celebić A, Lazić B, Baucić I, Komar D, Stipetić-Ovcaricek J, Ibrahimagić L. Influence of age and gender on radiomorphometric indices of the mandible in removable denture wearers. Coll Antropol 2002 Jun; 26(1):259-66.

26. Krall AE, Garcia DW, Dawson- Huhges B. Increased risk of tooth loss is related to bone loss at the whole body, hip and spine. Calc Tiss Int 1996; 59:433-437.

https://doi.org/10.1007/BF00369206

27. Martin RB, Burr DB, Sharkey NA. Skeletal tissue mechanics. New York: Springer; 1998.

https://doi.org/10.1007/978-1-4757-2968-9

28. Caroli A, Poli A, Ricotta D, Banfi G, Cocchi D. Invited review: Dairy intake and bone health: a viewpoint from the state of the art. Journal of Dairy Science 2011; 94(11):5249-5262.

https://doi.org/10.3168/jds.2011-4578

29. Praškevičius A, Burneckienė J. Biochemistry of the bone, teeth and saliva. Kaunas: KMU leidykla, 2000; 44.

30. Alekna V, Tamulaitienè M, Krasauskienė A. Diagnostics and treatment of osteoporosis. Lietuvos endokrinologija, 2003; 11:94-108.

31. Ross AC, Manson JE, Abrams SA, Aloia JF, Brannon PM, Clinton SK, et al. The 2011 Report on dietary reference intakes for calcium and vitamin $\mathrm{D}$ from the institute of medicine: what clinicians need to know? Department J Clin Endocrinol Metab 2011; 96(1):53-58.

https://doi.org/10.1016/j.jada.2011.01.004

32. Gulsahi A, Yüzügüllü B, Imirzalioglu P, Genç Y. Assessment of panoramic radiomorphometric indices in Turkish patients of different age groups, gender and dental status. Dentomaxillofac Radiol 2008 Jul; 37(5):288-92.

https://doi.org/10.1259/dmfr/19491030

33. Govindraju P, Kumar TSM, Chandra P, Balaji P, Sowbhagya MB. Panoramic radiomorphometric indices of mandible: biomarker for osteoporosis. In: Preedy VR, editor, Karnataka. Springer Science, 2015; 1-23.

https://doi.org/10.1007/978-94-007-7745-3_13-1

34. Dhanwal DK. Thyroid disorders and bone mineral metabolism. Indian Journal of Endocrinology and Metabolism 2011;15(2):107-112.

https://doi.org/10.4103/2230-8210.83339

35. Limeira FIR, Reboças RRM, Diniz DN, Melo DP, Bento PM. Decrease in mandibular cortical in patients with type 1 diabetes mellitus combined with poor glycemic control. Braz Dent J 2017; 28:552-558. 
https://doi.org/10.1590/0103-6440201701523

36. Caserta D, Ralli E, Matteucci E, Bordi G, Mallozzi M, Moscarini M. Combined oral contraceptives: health benefits beyond contraception. Panminerva Med 2014; 56:233-244.

37. Lopez LM, Chen M, Mullins S, Curtis KM, Helmerhorst FM. Steroidal contraceptives and bone fractures in women: evidence from observational studies. Cochrane Database of Systematic Reviews 2015; 21(7).

https://doi.org/10.1002/14651858.CD009849.pub3

\section{APATINIO ŽANDIKAULIO TANKIOSIOS KAULINĖS MEDŽIAGOS INDEKSO RADIOMORFOMETRI- NIS VERTINIMAS TARP JAUNO IR VIDUTINIO AMŽIAUS LIETUVIU \\ R. Laurinčikas, E. Jagelavičienė, A. Ratkevičienė, D. Grinkevičienė}

Raktažodžiai: apatinis žandikaulis, apatinio žandikaulio tankiosios kaulinès medžiagos indeksas, panoraminè radiografija, osteoporozè.

Santrauka

Apatinio žandikaulio pamato tankiosios kaulinès medžiagos indeksas (MCI) yra kokybinis rodiklis, kuriuo vertinami pokyčiai už smakrinės angos ir siejami su skeleto kaulų mineralų tankio pokyčiais. Tyrimai rodo, kad vyrai ir moterys kauluose turi skirtingą kaulinę masę, tankị ir dinaminius procesus. Dauguma atliktų apatinio žandikaulio pamato tankiosios kaulinès medžiagos pokyčių tyrimų, susijusių su osteoporozės profilaktika ir gydymu, nagrinèja vyresnio amžiaus populiacijos dalị, dažniau moterų, nei vyrų, nes jų organizme kaulinès medžiagos pokyčiai yra greitesni ir ryškesni, o ypač suaktyveja pomenopauziniu periodu. Šiame tyrime keliame ir siekiame patvirtinti hipotezę, kad ne tik metabolinès ligos (tokios, kaip osteoporozė) gali paveikti kaulą, bet tankiosios kaulinès medžiagos rezorbcija ir išsisluoksniavimas gali atsirasti del skirtingu priežasčiu jauno ir vidutinio amžiaus individams, neturintiems jokių metabolinèms kaulų ligoms būdingų simptomų, esant normaliam kaulų mineralų tankiui bei nepriklausantiems rizikos grupei.

Adresas susirašinèti: dominyka.narb@gmail.com

Gauta 2019-11-27 